\title{
Diffusion of Innovation Patterns among Poverty Alleviation Agencies and Sustainable Development Challenges in the Niger Delta Region: The Rivers State Experience
}

\author{
Godwin B. Okon ${ }^{1}$ \\ ${ }^{1}$ Department of Mass Communication, Rivers State University of Science and Technology, Nigeria \\ Correspondence: Godwin B. Okon, Department of Mass Communication, Rivers State University of Science and \\ Technology, PMB 5080, Portharcourt, Nigeria. E-mail: Okon.godwin@ust.edu.ng
}

Received: February 7, 2014

Accepted: March 5, 2014 Online Published: April 14, 2014

doi:10.5539/res.v6n2p40

URL: http://dx.doi.org/10.5539/res.v6n2p40

\begin{abstract}
The thrust of this paper was predicated on how well the poverty alleviation agencies in Rivers state have been able to streamline the precepts of their programmes to square with the dynamics of diffusion of innovation with a view to according sustainability to poverty eradication. Two government agencies concerned with poverty alleviation - The Adolescent Project (TAP) and Empowerment Support Initiative (ESI) - were purposively sampled based on operational visibility between 1999 till date. Analysis was done through focal group discussions in the form of Participant Cluster Appraisal (PCA). Discussions revealed that the core programmes of the agencies did not permeate the grassroots. It was also revealed that the schemes were grossly ineffectual. It was further observed by aggregation that the schemes did not engender a better quality of life for baseline demographics since the vocational skills acquisition programmes did not translate into entrepreneurial ventures for participants. This by deduction was due to the fact that the diffusion of innovation pattern adopted by these agencies was predominantly downward and this made the participants to respond based on a bandwagon effect rather than a conviction of their innermost potentials and desires. In other words, the diffusion of innovation pattern of the agencies was vertical rather than lateral and this accounted for the predominant lack of sustainability. It was therefore recommended that the dialogic and horizontal pattern of diffusion of innovation should be adopted by poverty alleviation agencies so as to allow for collectivity of will among stakeholders. This by projection will evolve a synergistic framework that will ensure sustainability.
\end{abstract}

Keywords: alleviation, diffusion, empowerment, innovation, poverty, sustainable development

\section{Overview}

Development may not mean the same thing as modernization because the concept of modernization is often misconstrued for westernization. What underscores development is the enabling environment that allows for the realization and optimization of human potentials. The renewing of the mind is a platform for emancipation and liberation. The catalyst for this, however, is the message that embellishes an idea, concept etc, geared towards propelling an individual from ignorance to knowledge. That message in unequivocal terms is innovation.

In the light of the foregoing, Robinson (2009) notes that "innovation is an idea, behaviour, or object that is perceived as new by its audience". Therefore, messages of development (innovation) are geared towards attitudinal conditioning that leaves the individual favourably disposed to change. In the change process, two things abound - awareness of the development (innovation) and identification with the development. This in figurative terms epitomizes diffusion of innovation and adoption of innovation and serves to explain further the processes that engender and ensure change.

The pioneering works of Rogers (1962) brought to fore the concept -diffusion of innovation - and further illuminated it. Through an assemblage of empirical studies in the field of anthropology, sociology, and agricultural extension, he was able to show the series of processes innovations pass through before they become widely accepted.

As a growing and valid field of research interest, Baran and Davis (2000) note that "the diffusion of innovation paradigm has been consented with most findings from effects surveys and persuasion experiments" ( $\mathrm{p} .12)$. They 
further observed that in addition to guiding Third World development, the diffusion of innovation paradigm has laid the foundation for numerous promotional communication and social change programmes.

It has however been observed that the sustainability of change programmes, to a large extent, depends on how well their tenets and elements were clearly understood by the beneficiaries. If not well understood, it becomes a heat of the moment thing and fades away from the psyche of people when its benefits are yet to unfold. This somehow explains the emerging phenomenon of development focused governance in Africa.

In this regard, Okon (2010) observes that:

There is a growing concern in Africa over the observed disconnect between development programmes and their expected outcome. In Nigeria for instance, the various programmes put in place by successive governments seem to have merely pushed people further into poverty rather than produce the desired results. These failed programmes have no doubt accentuated the poor standard of living of majority of Nigerians especially rural dwellers. It has been hypothesized however, that for the country to achieve the dream of ranking among the top 20 economies in the world by 2020, rural poverty must be addressed (p. 31).

Poverty is endemic in Nigeria and by extension, Sub Saharan Africa. Tropical development index shows rural areas in Nigeria to be grossly enmeshed in poverty. Abject poverty in commonsensical terms is marked by the mind being completely bereft of ideas that can engender positive change.

At the front burner of the Millennium Development Goals (MDGs) is the issue of poverty. Poverty eradication from a perspective of structured constructs is a precondition for the attainment of other Millennium Development Goals. Herein lies the bedrock of passion and drive for the eradication of poverty in Africa.

The ideal however is to eradicate poverty within a sustainable framework that allows people to learn, think and act in ways that make it possible to imbibe the basic lessons of enhanced quality of life.

Deductively, therefore, well conceived and thought out diffusion of innovation patterns according to Rogers as espoused by Hanson and Maxcy (1996) are those that ensure "a widely participatory process of social change in a society as well as bringing about both social and material advancement for the majority of the people through their gaining greater control over their environment" (p. 337).

The concern of this study is therefore predicated on how well the intervention/ poverty alleviation agencies, in the Niger Delta region of Nigeria, have streamlined the precepts of their programmes to square with the dynamics of diffusion of innovation with a view to according sustainability to poverty eradication.

\section{The Setting}

The geographic entity referred to as the Niger Delta is a region in the Niger Delta sedimentary basin. The region is bounded in the east by the Calabar flank, on the west by the Benin flank, on the south by the Atlantic Ocean and the Gulf of Guinea. On the north however is the Anambra basin/Abakiliki anticlinorium.

In terms of sedimentary deposits, the Niger Delta comprises three main formations viz the Akata, Agbada and Benin formations. The Agbada formation interestingly constitutes the main hydrocarbon reservoirs of the region. About two thirds of Nigeria's oil and gas produced to date comes from the Agbada formation reservoir and is located mainly in growth falls and roll over anticlines of the Niger Delta.

Rivers state on the other hand is bounded on the south by the Atlantic Ocean, to the north by Imo State and Abia State, to the east by Akwa Ibom state and to the west by Bayelsa and Delta States. The socio-political structure of the state is two-tier - central government and local government. The state is made up of twenty-three (23) local governments.

\section{The Agencies}

The Adolescent Project (TAP) was set up in 2009 by Mary Odili, the wife of the former governor of Rivers State, to reorient adolescents in the state so as to inculculate citizenship skills needed for a better qualiity of life. The project offers job training and civic education to help young people stand on their own. Training covers life planning education, skills acquisition, computer education, chemical technology, hand crafts, creative arts, etc. This in every day parlance is referred to as youth empowerment.

The Empowerment Support Initiative (ESI) is an agency founded by the wife of the present Governor of Rivers State, Dame Judith Amaechi. It was inaugurated in 2008 with the sole purpose of empowering children, youth and women through the adoption of purposeful measures to better their lot and finally move them out of poverty 
into a new, improved and sustainable economic status. The avenues for achieving these as outlined by the agency include the promotion of basic education, improved health care values, providing opportunities for acquisition of necessary skills to compete in modern economy while advocating for self development.

In order to drive the vision, ESI, as an agent of development, has entered into collaborative schemes with notable government agencies like Greater Portharcourt City Development Authority (GPHCDA) as well as other nucleus agencies. Among outreaches, ESI has

- Empowered 113 women who are economically disadvantaged through the provision of commercial taxis

- Trained over 100 women drawn from the 23 LGAs on sewing and tailoring, hat making and military, bread making, fashion illustration, etc, soap making

- Vocational training on masonry, carpentry, painting, computer appreciation,etc.

\section{Focus Group Observations}

Both agencies and projects seem to share the same conceptual ideals. Their operations from cursory analysis appear to have the same diffusion of innovation pattern where conception and implementation of innovation tend to follow a downward pattern.

For TAP, focus group observation revealed the following:

- Its rehabilitation scheme was grossly ineffectual since the spate of teenage pregnancies seemed not to have abated.

- Its programmes did not structurally permeate the grassroots

- There was hardly any visibility concerning a framework for structural operations. Its scheme was fluid in nature.

- As a result of the foregoing, TAP only has blurred memories of its operations for posterity

Conversely, focus group observation concerning ESI shows that the agency/scheme has not been able to break new grounds in terms of the ideal of helping the baseline demographics realize their innermost potentials. Comparatively, though, ESI seems to have fared better than TAP in terms of media visibility but the core value question is still in dire straits.

- The cabbie scheme (ESI cabbies) has turned out to be a phenomenal failure since the cabbies are hardly seen on the roads.

- The scheme lacked penetration in terms of the rural populace

- Its online portal, though robust, does not serve the need of baseline demographics.

- By aggregation, the scheme has really not engendered a better quality of life for the people since the vocational training/skills acquisition programmes did not translate into entrepreneurial ventures for the participants.

Calculable projections from the foregoing indices show that the scheme may not stand the test of contemporary dynamics

\section{The Synthesis}

The diffusion of innovation patterns of the poverty alleviation agencies studied, as inferred from the focus group observations, was predominantly downwards and this on its own had fundamental drawbacks. The predominant drawback however rested on the fact that participants only responded to the change agent (agencies) based on a bandwagon effect rather than a conviction of their innermost desires and potentials. For TAP, its framework was not well structured since their ventures were inveigled in a lot of illusions. For ESI as well, many women were made to drive taxis and buses, as the case may be, without necessarily minding if it was their calling or not. This may however account for the fact that most of the cabs and buses are off the roads now.

The foregoing, no doubt, fits into the notions of change as espoused by Morris (2006). According to him, "the field of communication for change is dominated by two paradigms: diffusion and participation" (p. 8). These paradigms no doubt have distinct theoretical roots and differing emphasis in terms of programme designs and goals. Programmes targeted at rural dwellers are faced with development projects that foster one- way information flow from the government and its agencies to the rural areas. The communication models adopted for poverty alleviation schemes have been found to be based on the transmission model of communication in 
which innovation is envisioned as a thing external to people and communication is the movement of that information from the source (government) to the audience (rural populace).

Deductively, the diffusion of innovation patterns of poverty alleviation schemes in Rivers State, by extrapolation, have been found not to be participatory in approach.

\section{Sustainable Development Challenges}

Sustainable development is a product of collective will and wholesome compliance. Naturally, human beings are given to divergent views based on psychography and idiosyncrasies. This however manifests in the form of discordant opinion when development issues assume the centre stage. The foregoing at its best breeds parochialism and at its worst, sycophancy. This accounts for the non viability and sustainability of many of our development programmes, especially those geared towards poverty alleviation and brings to fore the issue of coercive and non-coercive compliance. Coercive compliance attracts the use of force or what one might term, though trite, the carrot and the stick. The carrot is used as a reward for the conformists and the stick as a punishment for the non conformists. In a situation like this, a lot of people, for fear of the stick and the expectation of a reward, are compelled to conform. Eventually, when the carrot and the stick are withdrawn, as the case often is, compliance drops and eventually dies. This explains why The Adolescent Project(TAP) is no more; with the Empowerment Support Initiative (ESI) still wobbling to create impact. On the other hand, non-coercive compliance is not induced by anything but is gained through empathy and participatory communication. Unlike the coercive compliance, non coercive compliance allows for transparency, honesty and trust. Here the people are made to see the situation as it is, weigh the odds for themselves and assess the benefits. If the benefits far outweigh the odds, compliance is assured. This form of compliance is long lasting because it is shaped by the favourable disposition of the people engendered by collaborative and participatory communication - this aptly describes the framework for synergy.

Enhancing synergy of will, purpose and orientation geared towards sustainable development is a deliberate, systematic and proactive process. It requires trust, transparency and a good knowledge of the socio-political dynamics of a given system. This approach makes available a thorough understanding of the interpersonal interlink among people and stakeholders, past conflicts, hot beds of manifold tensions that may affect the future process and derail interventions. When all these are brought to the fore, consensus and understanding evolve naturally and this brings about the ownership and sustainability of poverty alleviation programmes.

This view has been aptly espoused by Dollar as cited in Asadu (2009). According to him, "projects that involved beneficiaries had a $70 \%$ success rate while those that did not had a $10 \%$ success rate" (p. 77). The imputation therefore is that the higher the collectivity of will among stakeholders in a development programme, the longer the sustainability of that programme. This framework has been aptly described by Mefalopulos (2009) as "dialogic and horizontal" (p. 27).The platform for synergy is therefore predicated on the foregoing.

Synergy in this context is purpose driven and entails:

- Dialogue, participation, co-operation and sharing of knowledge and information.

- A comprehensive consideration of the needs of all players(beneficiaries of the poverty alleviation scheme)

- $\quad$ Convergence of conventional and new media

- Mutual respect for local contexts, values and cultures which in turn will facilitate a participatory process to address negative components.

Attaining synergy in will, purpose and interest among stakeholders/beneficiaries in development interventions is all encompassing. The gains are indeed overwhelming. Synergy when attained will:

- Increase support for development/ poverty alleviation programmes among people of influence.

- Increase development/ poverty alleviation programme managers' awareness of constraints in service delivery and help overcome these constraints.

- $\quad$ Create demand for and sustain use of vocations acquired through empowerment schemes.

- $\quad$ Bring about desired changes in behaviour and sustain practices over time.

- $\quad$ Establish public support for development / poverty alleviation programmes.

- $\quad$ Empower communities and individuals to make informed decisions and take effective action about their own social development. 
- $\quad$ Bring about changes in social values.

- $\quad$ Enhance participation while strengthening group dynamics.

\section{Building Synergy for Sustainability}

A review of contemporary trends shows that diffusion of innovation patterns that allow for grassroots participation is being wholesomely embraced in Asia, Latin America and parts of Africa (India, Pakistan, Honduras, Peru, Brazil, Zambia, Tanzania, Kenya, etc). Unfortunately, its gains have been slow and lower than its potential due to some ideological, methodological and structural impediment.

This however necessitates the need for technocrats and scholars, across the region, nation and state, to evolve ways of engaging everyone in processes that engender change. This no doubt will ensure participation and consultation on issues and opportunities that can ultimately lead to a higher quality of life.

\section{References}

Asadu, C. (2009). Anatomy of communication for development. Port Harcourt: University of Port Harcourt Press.

Baran, S., \& Davis, D. (2000). Mass communication theory: Foundations, ferment and future. New York: Wardsworth Thomson Learning.

Hanson, J., \& Maxcy, D. (1996). Notable selections in mass media. Conneticut: Dushkin publishing group/Brown Benchmark publishers.

Metalopulos, T. (2009). Participatory communication: A practical guide. Washington DC: The World Bank.

Morris, N. (2006). Communication theory. Retrieved from http://onlinelibrary.wiley.com/doi/10.1111 /J:1468-2885.2006+b 00290x/abstract

Narula, U. (2006). Communication models. New Delhi: Atlantic publishers Ltd.

Okon, G. (2010). Trado Modern Media for sustainable rural development in Nigeria. In E. Sooal, H. Betta, \& C. Nwabueze (Eds.), Communication and Africa's development crisis: Essays in honour of Professor Des Wilson (pp. 31-41). Germany: VDM and Co. KG.

Robinson, L. (2009). A summary of diffusion of innovations. Retrieved from http://www.enbalingchange.com.au /Berg-engaging.pdf

Rogers, E. (2003). Diffusion of innovations (5th ed.). New York: Free Press.

\section{Copyrights}

Copyright for this article is retained by the author(s), with first publication rights granted to the journal.

This is an open-access article distributed under the terms and conditions of the Creative Commons Attribution license (http://creativecommons.org/licenses/by/3.0/). 